\title{
Multi Traits of Phosphate Solublizing Bacterial and Fungal Isolates and Evaluation of Their Potential as Biofertilizer Agent for Coffee Production
}

\author{
Reshid Abafita Abawari ${ }^{1, ~}$, Fasil Asefa Tuji ${ }^{2}$, Diriba Muleta Yadete ${ }^{3}$ \\ ${ }^{1}$ Department of Microbial, Cellular and Molecular Biology, Jimma Agricultural Research Centre, Jimma, Ethiopia \\ ${ }^{2}$ Department of Microbial, Cellular and Molecular Biology, Addis Ababa University, Addis Ababa, Ethiopia \\ ${ }^{3}$ Institute of Biotechnology, Addis Ababa University, Addis Ababa, Ethiopia
}

Email address:

reshida5@gmail.com (R. A. Abawari)

${ }^{*}$ Corresponding author

\section{To cite this article:}

Reshid Abafita Abawari, Fasil Asefa Tuji, Diriba Muleta Yadete. Multi Traits of Phosphate Solublizing Bacterial and Fungal Isolates and Evaluation of Their Potential as Biofertilizer Agent for Coffee Production. International Journal of Applied Agricultural Sciences.

Vol. 7, No. 1, 2021, pp. 1-15. doi: 10.11648/j.jjaas.20210701.11

Received: December 7, 2020; Accepted: December 17, 2020; Published: January 12, 2021

\begin{abstract}
Exploitation of phosphate solubilizing bacteria (PSB) and fungi as bioinoculants instead of chemical fertilizers is known to promote plant growth through the supply of plant nutrients. In view of this, the present investigation was planned to assess the phytobeneficial traits of phosphate solublizing bacterial and fungal isolates recovered from coffee arabica rhizosphere/ vermicompost and to determine their potential in growth promotion of coffee seedlings. They were isolated and purified following standard methods. A total number of 154 bacteria and 72 fungi were isolated from vermicompost and coffee rhizosphere. Out of these, twelve potent bacterial and nine fungal isolates were selected and investigated. Among twelve bacterial isolates, three of them showed significant potential to solubilize $\mathrm{Ca}_{3}\left(\mathrm{PO}_{4}\right)_{2}$ and had phytobeneficial traits, viz, indole acetic acid, $\mathrm{NH}_{3}, \mathrm{HCN}$ production and $\mathrm{N}$-fixing ability. The three bacterial isolates $\left(\mathrm{RCHVCB}_{1}, \mathrm{RScB} 1.19\right.$ and $\left.\mathrm{RMaB} 2.11\right)$ exhibited also remarkable tolerance to ecophysiological factors such as heavy metal, acidity and salinity. These potent isolates were selected for further identification based on morphological and biochemical characteristics and presumptively identified as genera of Pseudomonas $\left(\mathrm{RCHVCB}_{1}\right)$ and Bacillus (RScB1.19 and RMaB2.11). Similarly, three fungal isolates with superior phosphate solubilizeation ability were characterized and identified as genera Penicillium (RSCF1.19) and Aspergillus (RCHVCF2 and RLVCF2). Consequently, these three efficient bacterial and fungal isolates were evaluated on the coffee seed germination on Petri dish based trial under laboratory condition. The results of inoculated seeds showed significant $(\mathrm{p} \leq 0.05)$ differences in germination rate and vigor index compared to the control. Among all inoculums RScB1.19, RMaB2.11+RSCF1.19 and RMaB2.11 + RLVCF2 showed significantly $(p \leq 0.05)$ high germination rate $(20.59 \%)$ over the control (13.33\%). Moreover, a single inoculation of RLVCF2, RSCF1.19 and co-inoculation of RMaB2.11 with RLVCF2 also showed significant $(\mathrm{p} \leq 0.05)$ mean root length $(1.31 \mathrm{~cm})$ and mean shoot length $(1.48 \mathrm{~cm})$ over the control. These effective bacterial and fungal solublizers can be recommended under field condition as biofertilizer agent and reducing the cost required for chemical fertilizers and providing a step forward towards sustainable agriculture.
\end{abstract}

Keywords: Germination, Phosphate Solubilization, Bioinoculants, Phytobeneficial, Ecophysiology

\section{Introduction}

Bio-inoculants are one of the important technology that create very significant impact on farmers as they are cost effective and renewable resource in making nutrients (macro and micronutrients) available to plants to supplement the chemical fertilizers for sustainable agriculture. Among macro-nutrients phosphorus (P) plays critical roles in plant nutrition [1]. Organic matter and inorganic compounds are major sources of available $\mathrm{P}$ in the soil [2]. The insoluble and inaccessible forms of $\mathrm{P}$ are hydrolyzed to soluble and available forms through the process of solubilization of 
inorganic $\mathrm{P}$ and mineralization of organic $\mathrm{P}$ [3]. Of the various chemical forms of $\mathrm{P}$, plants take up only negatively charged primary and secondary orthophosphate ions $\left(\mathrm{H}_{2} \mathrm{PO}_{4}^{-}\right.$ and $\mathrm{HPO}_{4}{ }^{2-}$ ) as nutrient, but most of $\mathrm{P}$ in nature exists in various organic and inorganic forms. Therefore, the availability of $\mathrm{P}$ depends on the solubility of this element, which could be influenced by the activity of plant roots and microorganisms in the soil.

Phosphate-solubilizing microorganisms (PSMO) solubilize the insoluble forms of $\mathrm{P}$ such as tricalcium phosphate $\left(\mathrm{Ca}_{3}(\mathrm{PO} 4)_{2}\right)$, aluminium phosphate $\left(\mathrm{AlPO}_{4}\right)$, or iron phosphate $\left(\mathrm{Fe}_{3} \mathrm{PO}_{4}\right)$ through the production of organic acids, siderophores, and hydroxyl ions [4]. Some bacteria only solubilize calcium phosphate, while other microorganisms are capable of solubilizing other forms of inorganic phosphates at different intensities. Bacterial isolates belonging to genera Enterobacter, Pantoea and Klebsiella solubilize $\mathrm{Ca}_{3}\left(\mathrm{PO}_{4}\right)_{2}$ to a greater extent than $\mathrm{FePO}_{4}$ and $\mathrm{AlPO}_{4}$ [5]. The production of organic acids, particularly gluconic and carboxylic, is one of the well-studied mechanisms utilized by microorganisms to solubilize inorganic phosphates [6].

Several phosphate solublizing bacteria (PSB) have been isolated from the roots and rhizospheric soil of various plants [7]. Chen et al. [8] have previously reported several PSB strains belonging to the genera Bacillus, Rhodococcus, Arthrobacter, Serratia, Chryseobacterium, Gordonia, Phyllobacterium. Later, Souza et al. [7] have identified isolates belonging to the genera Burkholderia, Cedecea, Cronobacter, Enterobacter, Pantoea and Pseudomonas which were able to solubilize $\mathrm{Ca}_{3}\left(\mathrm{PO}_{4}\right)_{2}$. Moreover, an earlier report by Suhane [9] showed that the abundance of phosphate solublizers in vermicompost indicating its potential to screen phytobeneficial microbes from natural pool. Biswas et al. [10] have demonstrated the efficiency of bacteria isolated from the gut of earthworm in solubilizeation of $\mathrm{Ca}_{3}\left(\mathrm{PO}_{4}\right)_{2}$ by tolerating higher concentration of heavy metals such as $\mathrm{Cu}$ and $\mathrm{Zn}$. Esakkiammal et al. [11] have also reported that the fungal population is found to be significantly higher in the fresh vermicast obtained from vermicompost of Eudrilus eugeniae and Eisenia fetida. Likewise, Anastasi et al., [12] have isolated and documented a total of 142 fungal species that are associated with vermicompost.

Penicillium and Aspergillus spp. are the dominant Psolubilizing filamentous fungi found in rhizosphere [13]. They are said to be the most powerful $P$ solubilizers [14]. Filamentous fungi are highly important in P solubilization. It was reported that Aspergillus niger and Trichoderma harzianum could be potential candidate for developing bioinoculants to facilitate $\mathrm{P}$ supply to different crops in alkaline and acidic soils with organic and inorganic $\mathrm{P}$ content and also possessed plant growth promoting attributes such as auxin and sidreophore production [15]. Earlier reports by Pandey [16] and Pindi [17] were indicated that some Penicillium species and Aspergillus niger have a potential role in Rock Phosphate solubilizeation, $\mathrm{P}$ mobilization and tend to accelerate plant growth promotion using different strategies.
Thus, there is a need for rigorous screening of efficient PSMO with adaptation to different soil conditions [18] with due emphasis on vermicompost and coffee rhizosphere thereby to increase organic coffee production and productivity. In Ethiopia few studies dealt with phytobeneficial microbes associated with coffee Arabica. For instance, Muleta et al [19] have conducted in vitro assessment on $\mathrm{P}$ solubilising ability of rhizobacteria associated with Coffea arabica L. using hydroxyapatite and tricalcium phosphate and reported that over $72 \%$ of tested genera of Pseudomonas and Erwinia were able to release free $\mathrm{P}$ from complex compounds. Nevertheless, development of effective microbial bio-inoculants under in vivo condition for coffee production and importance of bio-inoculant technologies are yet to be done in coffee production sector. Therefore, the present study was designed with the aim of studying morphological and physiological characteristics of the indigenous $\mathrm{P}$ solubilizing bacteria and fungi associated with vermicompost and coffee rhizosphere to assess their potential to increase coffee germination rate under laboratory condition.

\section{Materials and Methods}

\subsection{Description of the Study Areas}

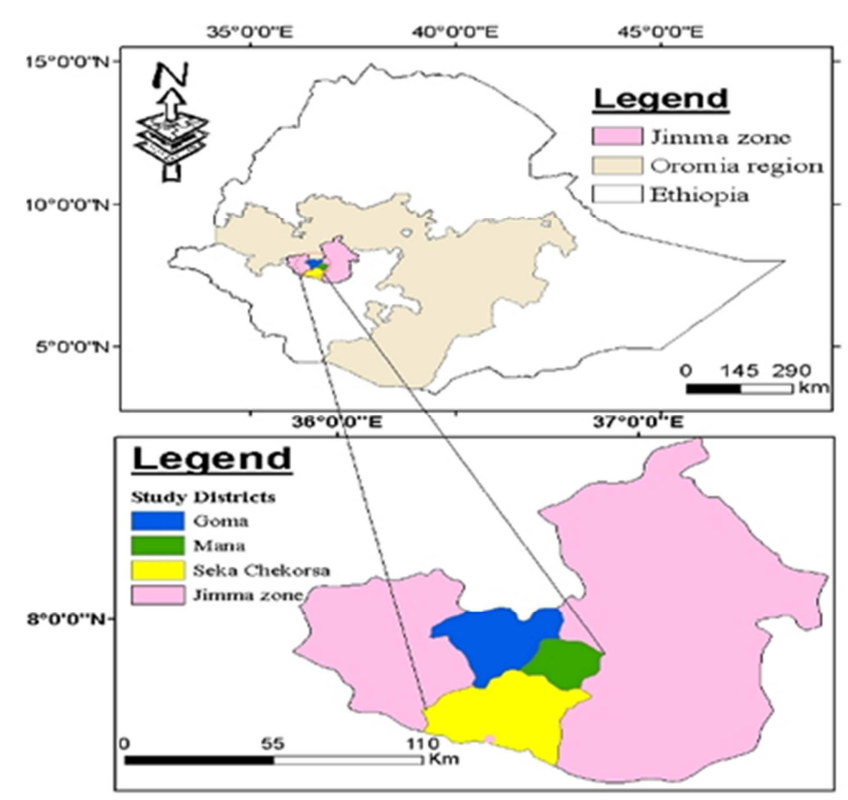

Figure 1. Soil sample collection area.

The study was carried out at Jimma Agricultural Research Center (JARC) during 2018/2019. JARC is located at $363 \mathrm{~km}$ to the southwest of Addis Ababa. JARC is found at $7^{\circ} 40^{\prime} 47^{\prime \prime} \mathrm{N}$ latitude and $36^{\circ} 49^{\prime} 47^{\prime \prime} \mathrm{E}$ longitude. The mean minimum and maximum temperature of JARC are 26.2 and $11.3^{\circ} \mathrm{C}$, respectively. The elevation of the Center is $1,753 \mathrm{~m}$ above sea level and it receives $1,529.5 \mathrm{~mm}$ average annual rainfall. The total area of Jimma Zone is $18415 \mathrm{~km}^{2}$ and located between latitudes $7^{\circ} 18^{\prime} \mathrm{N}$ and $8^{\circ} 56^{\prime} \mathrm{N}$ and longitudes $35^{\circ} 52^{\prime} \mathrm{E}$ and $37^{\circ} 37^{\prime} \mathrm{E}$. Soil samples were collected from Seka 
Chekorsa, Goma and Manna districts of Jimma Zone (Figure 1). Seka chekorsa, Goma and Manna districts are among the woredas in Jimma zone, which are located at 368, 368 and $395 \mathrm{~km}$ respectively, southwest of Addis Ababa. The microbial analysis was conducted in Jimma University, School of veterinary medicine Laboratory.

\subsection{Vermicompost Production}

Green grass ( $\mathrm{Gg}$ ) was collected from JARC, chopped and subjected to initial decomposition in draining plastic containers of $45 \times 35 \times 15 \mathrm{~cm}$ sizes by sprinkling water, regular mixing and turning of the substrates for 15 days. Cow dung (CD) was collected from nearby cattle sheds in fresh form and allowed to dry in open space for one week and used for the study. The Russian based earthworms, Eisenia fetida, originally collected from vermiculture of the JARC were mass multiplied in cow dung and used for the study. Each pre-decomposed Gg and CD substrates were mixed in 1:2 ratio, respectively on dry weight basis by making piles in plastic containers of $45 \times 35 \times 15 \mathrm{~cm}$ size and was left for a period of 4 days for stabilization by sprinkling water daily. After 4 days, each bin containing vermibed substrate was introduced with 200 adult E. fetida. Vermicomposting was carried out in an environmentally controlled experimental glass house at a temperature of $26 \pm 2{ }^{\circ} \mathrm{C}$ and the vermibeds were maintained to contain a moisture level of $(65-75 \%)$ by sprinkling water over the surface at two days intervals until maturity.

\subsection{Collection of Soil and Vermicompost Samples}

Over 150 soil samples were collected from commonly known coffee growing districts of Mana, Goma and Seka Chokorsa in Jimma Zone, Oromia Regional State. The soil samples obtained from a depth of $0-15 \mathrm{~cm}$ from the rhizosphere adhering to roots of coffee plants. The samples were randomly collected from coffee plantation fields/farmers managed forest coffee/ within 1 to $2 \mathrm{~km}$ interval between the samples. Matured vermicompost was collected and air dried under shade for the isolation of phytobeneficial bacteria and fungi as described by Kole \& Altosaar [20]. All samples were placed in polythene bags, brought to the laboratory in ice boxes and were stored at $4{ }^{\circ} \mathrm{C}$ in refrigerator for further analysis. The $\mathrm{pH}$ of soil sample and vermicompost was measured from the suspension of $1: 2.5$ soils: $\mathrm{H}_{2} \mathrm{O}$ by $\mathrm{pH}$ meter. Soil and vermicompost determination of OC was done following Wakley and Black [21] method and available NPK was also analyzed based on Bray II procedure [22].

\subsection{Isolation of Microbes}

Primary isolation and identification of fungal and bacterial $\mathrm{P}$ solublizers was done on Pikovskaya's agar (PVK), containing per liter: $0.5 \mathrm{~g}$ yeast extract, $10 \mathrm{~g}$ dextrose, $5 \mathrm{~g}$ $\mathrm{Ca}_{3}\left(\mathrm{PO}_{4}\right)_{2}, 0.5 \mathrm{~g}\left(\mathrm{NH}_{4}\right)_{2} \mathrm{SO}_{4}, 0.2 \mathrm{~g} \mathrm{KCl}, 0.1 \mathrm{~g}, \mathrm{MgSO}_{4} .7 \mathrm{H}_{2} \mathrm{O}$, $0.0001 \mathrm{~g}, \mathrm{MnSO}_{4} \cdot \mathrm{H}_{2} \mathrm{O}, 0.0001 \mathrm{~g}, \mathrm{FeSO}_{4} .7 \mathrm{H}_{2} \mathrm{O}$ and $15 \mathrm{~g}$ agar, $\mathrm{pH}$ 7.2) supplemented with tri-calcium phosphate $(5 \mathrm{~g} / \mathrm{L})$ as an insoluble inorganic phosphate source [23 [by plate count method [24]. $10 \mathrm{ml} / \mathrm{L}$ Rose Bengal was added for control of bacterialgrowth at concentration $1 / 15000$ to PVK for fungal growth [25]. A $10 \mathrm{~g}$ of soil and vermicompost was separately suspended in $90 \mathrm{ml}$ sterile distilled water in Erlenmeyer flask and mixed thoroughly for 30 minutes using a mechanical shaker at $110 \mathrm{rpm}$. Then $1 \mathrm{ml}$ of aliquot from each was transferred with sterile pipettes for ten-fold serial dilution. From appropriate serial dilution, $0.2 \mathrm{ml}$ of aliquot was transferred to sterile Petri-plate containing pre-solidified PVK medium. The inoculated plates were incubated for 7-14 days at $30^{\circ} \mathrm{C}$ for bacterial isolation and incubated for 6 days at $25 \pm 2^{\circ} \mathrm{C}$ for fungal isolation. From the total colonies, only those colonies which showed clear zones were re-streaked onto PVK medium to obtain pure cultures of phosphate solublizing colonies. The pure colonies that showed clear zones around them were maintained in PVK slants at $4^{\circ} \mathrm{C}$ for subsequent analysis.

\subsubsection{Phosphate Solubilization Tendency of Isolates}

The P-solubilization index (SI) of phosphate solubilizing bacterial and fungal isolates were checked on the PVK medium supplemented with tri-calcium phosphate $(5 \mathrm{~g} / \mathrm{L})$ as insoluble phosphates source. A pinpoint inoculation of bacterial and fungal isolates was placed on the center of plates under aseptic conditions. The growth and solublization of insoluble phosphates in the PVK medium by forming the halo zones were determined by solubilization diameter after incubation at $30^{\circ} \mathrm{C}$ for 7 days for bacteria and at $25 \pm 2^{\circ} \mathrm{C}$ for 6 days for fungi. Bacterial and fungal colonies surrounded by a halo, indicating phosphate removal, were visually observed and measured [26]. Three replicate plates were used for each isolate. The solubilization index was measured according to the formula:

$$
\text { PSI }=\frac{\text { Colony diameter }+ \text { halozone diameter }}{\text { Colony diameter }}
$$

\subsubsection{Solubilization of Inorganic Phosphate in Liquid Medium}

Pikovskaya's broth medium $(125 \mathrm{ml})$ supplemented with $0.5 \%$ TCP (equivalent to $5000 \mathrm{mg} \mathrm{L}^{-1}$ ) was prepared. The medium in $125 \mathrm{ml}$ amount was dispensed into a $250 \mathrm{ml}$ capacity Erlenmeyer flask. Three replicate flasks were used for each bacterial and fungal isolate. Sterile uninoculated medium was served as control. The $\mathrm{pH}$ of the medium was adjusted to 7.0 before autoclaving and each flask was inoculated with $0.1 \mathrm{ml}$ of $24 \mathrm{~h}$ old active culture suspensions of each PS bacterial isolates with a cell density of $10^{8} \mathrm{cuf} / \mathrm{ml}$. Similarly, the liquid medium in the flasks was inoculated with fungal isolate using $8 \mathrm{~mm}$ mycelia disks taken from 7 days old cultures.

The flasks were kept on a rotary shaker $(125 \mathrm{rpm})$ for 6 days until the day of sampling for bacteria and kept for 15 days until the day of sampling for fungi. To collect solublized inorganic $P$ by bacteria, insoluble materials in each culture broth were removed by centrifuging at 4,000 rpm for 20 minutes and filtered through Whatman filter paper 
No. 1. To quantify solubilized $P$ in each fungal culture, insoluble materials were removed by centrifuging at 5,000 rpm for 25 minutes and filtered through Whatman filter paper No. 42. From each culture, $0.625 \mathrm{ml}$ of the filtrate was transferred to a volumetric flask of $100 \mathrm{ml}$ capacity and 13 $\mathrm{ml}$ of mixed reagent added. The volume was top upped to $100 \mathrm{ml}$ with distilled water. Soluble phosphorus was determined following quantitative spectrophotometric analysis according to the method of Murphy and Riley [27] and the $\mathrm{pH}$ of the cultures was also measured accordingly using $\mathrm{pH}$ meter [28]. The absorbance of blank and cultures of the inoculated treatment filtrates were read at $882 \mathrm{~nm}$ wave length using spectrophotometer (JENWAY 6100, JENWAY LTD, UK). A calibration curve for standard, plotting absorbance against respective $\mathrm{P}$ concentrations was prepared and the $\mathrm{P}$ concentration of treatment filtrates was read from calibration curve.

\subsection{Test for Phytobeneficial Traits}

\subsubsection{Production of Indole Acetic Acid (IAA)}

Production of IAA was done based on methodology of Patten and Glick [29]. The potent bacterial cultures were inoculated into nutrient broth with L-tryptophan $(5 \mu \mathrm{g} / \mathrm{mL})$ and incubated at $28 \pm 2{ }^{\circ} \mathrm{C}$ for 5 days. After incubation, cultures were centrifuged at $3000 \mathrm{rpm}$ for $30 \mathrm{~min}$. A $2 \mathrm{~mL}$ of the supernatant was mixed with 2 drops of orthophosphoric acid and $4 \mathrm{~mL}$ of Salkowski's reagent $\left(50 \mathrm{~mL}\right.$ of $35 \%$ perchloric acid $\left.+1 \mathrm{~mL} 0.5 \mathrm{FeCl}_{3}\right)$ and incubated in the dark for 25 minutes. Development of pink colour indicates IAA production.

\subsubsection{Production of Ammonia ( $\left.\mathrm{NH}_{3}\right)$}

Bacterial isolates were tested for the production of ammonia in peptone water. PSB was grown for $48 \mathrm{~h}$ in nutrient broth (NB) medium at $36 \pm 2{ }^{\circ} \mathrm{C}$. Freshly grown cultures ( $100 \mu \mathrm{L}$ of $24 \mathrm{~h}$ grown) were inoculated into $10 \mathrm{~mL}$ peptone water in each tube. Nessler's reagent $(0.5 \mathrm{ml})$ was added in each tube. Development of brown to yellow color was taken as a positive test for ammonia production [30].

\subsubsection{Hydrogen Cyanide (HCN) Production}

Qualitative cyanide determination was carried out by Lorck [31] method modified by Alstrom and Burns [32]. PSB isolates were sub cultured onto nutrient agar (NA) medium supplemented with glycine $\left(4.4 \mathrm{gL}^{-1}\right)$. Whatman filter paper No. 1 soaked in $2 \%$ sodium carbonate in $0.5 \%$ picric acid solution was placed at the top of the plate fixed to the underside of the Petri-dish lids and sealed with parafilm before incubation at $28^{\circ} \mathrm{C}$ for $48 \mathrm{~h}$. Changes in color from yellow to reddish brown was taken as an indication of strongly cyanogenic potential.

\subsubsection{Nitrogen Fixing Activity}

In order to screen for nitrogen fixing ability among the isolated PSB, the pure cultures were inoculated onto Jensen's medium [33] containing g/L: Sucrose 20.0, Dipotassium phosphate 1.0, Magnesium sulphate 0.5, Sodium chloride 0.5, Ferrous sulphate 0.1, Sodium molybdate 0.005, Calcium carbonates 2.0, Agar 15.0. The inoculated Petri plates were incubated at $37^{\circ} \mathrm{C}$ for 5 days. Un-inoculated Petri plate served as control.

\subsection{Test for Eco-physiological Properties}

\subsubsection{Evaluation for Heavy Metal Tolerance}

Tolerance to heavy metals was measured using PVK medium [23] supplemented with different concentrations of various soluble heavy metal salts. Freshly prepared agar plates were amended with various soluble heavy metal salts namely $\mathrm{Hg}, \mathrm{Cu}, \mathrm{Zn}$ and $\mathrm{Mn}$, at various concentrations ranging from 100 to $400 \mu \mathrm{g} / \mathrm{ml}$ was inoculated with overnight grown cultures in PVK medium. Heavy metal tolerance was determined by the appearance of bacterial growth after incubating the plates at $37^{\circ} \mathrm{C}$ for $48 \mathrm{~h}$. Isolates were considered resistant when growth was observed ("+") and ("-") for absence of growth.

\subsubsection{Evaluation for Salinity Tolerance}

PVK medium supplemented with different concentrations of $\mathrm{NaCl}(3 \%, 4 \%, 5 \%, 6 \%$ and $7 \%(\mathrm{w} / \mathrm{v})$ were used to screen the P-solubilization efficacy of different isolates and it was incubated at $28^{\circ} \mathrm{C}$ for 5 days [34]. The results were recorded qualitatively as ("+") for presence and ("-“") for absence of growth indicating the salt tolerance and sensitivity level of the microbes.

\subsubsection{Screening for Acid Tolerance}

PSB isolates were tested for $\mathrm{pH}$ tolerance according to the method described by Hayat et al. [35]. To analyze whether bacteria can grow in a range of $\mathrm{pH} 4.0$ to 10.0 at an increment of one unit $\mathrm{pH}$, all the active strains of PSB were inoculated separately into test tubes containing $10 \mathrm{ml}$ of nutrient broth (NB) at varying $\mathrm{pH}$ levels adjusted with sterile $0.1 \mathrm{~N} \mathrm{HCl}$ and $1 \mathrm{~N} \mathrm{NaOH}$. Bacteria were incubated for 8 days at $25^{\circ} \mathrm{C}$. The results were recorded qualitatively as ("+") for presence and ("-") for absence of growth.

\subsection{Identification of PSM}

The selected PSB isolates were studied for their morphological, physiological and biochemical tests based on the methods defined in Bergey's Manual of Determinative Bacteriology [36]. Bacterial colonies from purified culture were grown on PVK solid medium by streak plate method and incubated at $30^{\circ} \mathrm{C}$ until colonies appeared. Gram staining reaction of isolates was observed under light microscope. Morphological characters of the fungal isolates were observed by growing them on PVK agar and stained with lectophenol cotton blue stain for observation of morphological characteristics of the hyphae, spores, and conidiophores under light microscope.

\subsection{Multiplication of Bacterial and Fungal Isolates and Inoculum Preparation}

Inoculum of PSB was prepared in Pikovskaya's broth medium. After multiplication of the selected elite isolates in the PVK broth by incubating at $28 \pm 2^{\circ} \mathrm{C}$ under shaking at 100 rpm for three days, the broth culture was mixed with sterilized 
vermicompost (VC) as carrier material. The viable count in the inoculum was kept as $1 \times 10^{8} \mathrm{CFU} / \mathrm{ml}$ before mixing with carrier material (VC) that was sterilized at $121^{\circ} \mathrm{C}$ and $15 \mathrm{psi}$ pressure for one hour. Proper water content of the sterile carrier material (VC) was maintained and inoculated with broth cultures of phosphate solublizing isolates $(20 \mathrm{~mL}$ per 50 $\mathrm{g}$ of $\mathrm{VC}$ ) and was incubated at $28 \pm 2^{\circ} \mathrm{C}$. For fungal inoculums preparation, phosphate solubilizing fungal (PSF) isolates were mass cultured aseptically in $90 \mathrm{~mm}$ diameter Petri plates each containing $15 \mathrm{~mL}$ of autoclaved PVK. The plates were incubated at $28 \pm 2{ }^{\circ} \mathrm{C}$ for 10 days. On the tenth day, spore suspensions from the fungal isolates was prepared by flooding the surface of the agar with $10 \mathrm{~mL}$ sterile distilled water and the culture surface gently scraped using a sterile glass rod to dislodge the spores. The spore suspension was transferred separately to $500 \mathrm{~mL}$ flask containing $400 \mathrm{~mL}$ sterile distilled water. Flasks were shaken for 2 minutes to ensure that the spores were properly mixed. The cultures were filtered through Whatman No. 42 filter paper into sterile glass bottle. The spore suspension of $25 \mathrm{ml}$ of fungal culture was used per $50 \mathrm{~g}$ of the sterilized carrier material (VC) and immediately stored at $4{ }^{\circ} \mathrm{C}$ until use. The mixed and inoculated carrier material was evaluated for plant growth promotion as bio-inoculants for seed germination under laboratory condition on Petri plates

\subsection{Seed Germination Assay}

Healthy seeds of coffea arabica L. (Variety 74110) that were coffee berry disease (CBD) tolerant, high yield bearing and released variety were obtained from JARC. Coffee variety 74110 is high yielding variety, suitable for medium altitudes and collected from Illu Ababor in Eastern Ethiopia district [37]. The seeds were surface sterilized by immersing in $3.25 \%(\mathrm{v} / \mathrm{v})$ sodium hypochlorite for $1 \mathrm{~min}$, followed by $70 \%(\mathrm{v} / \mathrm{v})$ ethanol for $1 \mathrm{~min}$ and rinsing five times in sterile distilled water. These seeds were submerged in liquid $4 \mathrm{ml}$ of fungal spore suspension and bacterial cultures, both as single and dual inoculation separately for $6 \mathrm{hr}$ incubation at room temperature [38]. The seeds were dried in a laminar air-flow. The Seed germination assay was done with completely randomized design (CRD) in three (3) replications per treatments and arranged in two groups. The first group was designed with six $\left(\mathrm{T}_{1}-\mathrm{T}_{6}\right)$ treatments for single inoculation and the second group were designed with ten $\left(T_{7}-T_{16}\right)$ treatments for co-inoculation. A total of 10 seeds were placed at equal distance on the sterile moist blotter paper of $8.5 \mathrm{~cm}$ diameter in pre-sterilized borosil glass Petri dishes of $10 \mathrm{~cm}$ diameter. The seeds were covered with other moist blotter paper and these Petri dishes were incubated for 50 days at room temperature. During these days, sterile distilled water was properly added to maintain wet condition. After incubation period, percent seed germination, shoot (plumule) and root (radicle) length of each seeds was recorded. The germination rate and vigor index were calculated according to the following equations [39]:

$$
\text { Germination rate }(\%)=\frac{\text { Number of seeds germinated }}{\text { Total number of seeds }} \times 100
$$

Vigor index $=\%$ Seed germination $\times[$ Mean root (radicle) Length + Mean Shoot (plumule) Length $]$

\subsection{Statistical Analysis}

The experimental results are presented in the form of tables using Microsoft Excel 2007. Data obtained from the different treatments were statistically analyzed using the one-way ANOVA and the mean values were compared by the Duncan's multiple range tests for multiple comparisons. Differences was considered significant at the 0.05 level using SAS origin software (Version 8.5.0) 2010, Origin Lab Corporation.

\section{Results}

\subsection{Physico-chemical Properties of Soil and Vermicompost}

Physio-chemical parameters of rhizosphere soil samples and vermicompost were determined and presented in Table 1. The soil $\mathrm{pH}$ of study site and vermicompost was in the range of 4.6-6.2 and 8.5-9.5 respectively (Table 1). The organic carbon and the extractable phosphorus concentration recorded from study site were in the range of $0.63-0.87 \%$ and $10.12-10.30 \mathrm{ppm}$ respectively, which are in the very low range $[40,41]$. However, the organic carbon and the extractable phosphorus concentration recorded from vermicompost were in the high range. The potassium concentration of the study site was also in the range of 60.04$102.86 \%$ which is in the high range (Table 1) [40]. The total $\mathrm{N}$ concentration of the study site and vermicompost were in the range of $0.04-0.11 \%$ and $1.23-1.24$ respectively (Table $1)$, which is in the low range $[40,4]$.

\subsection{Isolation and Characterization of Bacterial and Fungal Isolates}

A total of PSB and fungi isolated from coffee rhizosphere and vermicompost isolated on PVK agar medium from the study area are presented in Table 2. Some of the colonies which produced halo around them on the PVK agar were considered as phosphate solubilizers and selected for characterization. A total number of 154 bacteria and 72 fungi were isolated from vermicompost and coffee rhizosphere (Table 2). 
Table 1. Physico - chemical characteristic of Soil samples and Vermicompost sample collected.

\begin{tabular}{|c|c|c|c|c|c|c|c|c|c|}
\hline Samples & $\begin{array}{l}\text { Sampling } \\
\text { area/source }\end{array}$ & $\begin{array}{l}\text { Sample } \\
\text { color }\end{array}$ & $\begin{array}{l}\text { CEC } \\
(\mathrm{meq} / \mathbf{1 0 0 g})\end{array}$ & $\begin{array}{l}\text { Organic } \\
\text { C }\end{array}$ & $\% \mathrm{TN}$ & $\begin{array}{l}\text { Available P } \\
\text { (ppm) }\end{array}$ & K (\%) & $\begin{array}{l}\text { pH ( } \mathrm{H}_{2} \mathrm{O}: \\
1: 2.5)\end{array}$ & $\begin{array}{l}\text { Ex. Acidity } \\
\text { (meq/100g }\end{array}$ \\
\hline Rgo 3.17 & Goma & Light grey & 13.00 & 0.87 & 0.07 & 10.36 & 65.04 & 6.2 & 0.40 \\
\hline RMa 2.39 & Manna & Light grey & 12.12 & 0.83 & 0.07 & 13.10 & 102.86 & 5.6 & 0.50 \\
\hline RCHVC1 & Vermicompost & black & 20.84 & 10.83 & 1.24 & 295.998 & 100.33 & 9.5 & 0.67 \\
\hline RSC1.50 & Seka chekorsa & Red & 14.78 & 0.66 & 0.20 & 169.16 & 60.04 & 4.6 & 0.30 \\
\hline RLVC 2 & Vermicompost & black & 20.80 & 10.83 & 1.24 & 295.998 & 89.87 & 9.5 & 0.66 \\
\hline RSc 1.19 & Seka chekorsa & red & 14.70 & 0.63 & 0.11 & 168.10 & 64.04 & 4.86 & 0.59 \\
\hline Rgo 3.5 & Goma & grey & 13.18 & 0.81 & 0.05 & 10.30 & 102.86 & 5.52 & 0.41 \\
\hline RSc 1.7 & Manna & grey & 14.14 & 0.82 & 0.04 & 13.33 & 102.86 & 6.1 & 0.43 \\
\hline RMa 2.11 & Manna & grey & 12.36 & 0.85 & 0.08 & 10.12 & 102.86 & 5.59 & 0.40 \\
\hline RMa 1.2 & Manna & brown & 15.6 & 0.84 & 0.08 & 13.30 & 102.86 & 5.55 & 0.40 \\
\hline
\end{tabular}

Table 2. Total number of bacteria and fungi isolated from samples.

\begin{tabular}{|c|c|c|c|c|c|}
\hline \multirow{2}{*}{$\begin{array}{l}\text { Sources of soil } \\
\text { samples }\end{array}$} & \multicolumn{3}{|l|}{ Bacterial Isolates } & \multicolumn{2}{|l|}{ Fungal isolates } \\
\hline & Number of samples & Number of PSB & Proportion of PSB (\%) & Number of PSF & Proportion of PSF isolates (\%) \\
\hline $\mathrm{VC}$ & 6 & 54 & 35.07 & 42 & 58.34 \\
\hline Coffee rhizosphere & 120 & 100 & 64.94 & 30 & 41.67 \\
\hline Total & 126 & 154 & 100 & 72 & 100 \\
\hline
\end{tabular}

$\mathrm{VC}=$ vermicompost

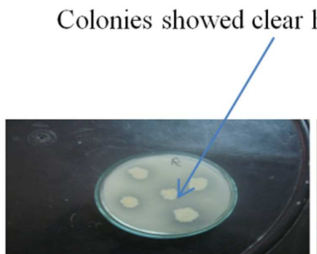

(A)

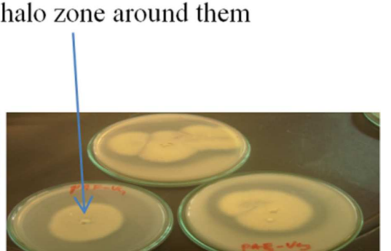

(B)
Figure 2. Bacteria and fungi showing clearly visible large halo zones around their colonies.

Among the 154 bacterial isolates, only 12 of them showed clearly visible large transparent halo zones around their colonies on PVK agar medium after 7 days of incubation (Figure 2A). Similarly among 72 fungal isolates, only 9 of them showed clearly visible large halo zones around their colonies on the same culture medium after incubation at $25 \pm 2^{\circ} \mathrm{C}$ for 6 days (Figure 2B).

\subsection{Phytobeneficial Traits of Bacteria Isolated from Vermicompost and Coffee Rhizosphere}

Among those twelve potent PSB isolates, strain RMaB2.11 showed the maximum phosphate solubilizing halo zone (15.33 $\pm 1.53 \mathrm{~mm}$; (Table 3). However, the solubilization index (SI) of the isolates RCHVCB1, RScB1.19 and RMaB2.11 were $3.87 \pm 0.12, \quad 3.56 \pm 0.14$ and $3.09 \pm 0.08$, respectively (Table 3 ). These indicated that the isolates solubilized inorganic phosphate efficiently in the medium containing $0.5 \%$ tri-calcium phosphate (TCP).

Table 3. Qualitative phosphate solubilization efficiency of bacterial isolate.

\begin{tabular}{llll}
\hline Isolate code & Colony diameter $(\mathbf{m m})$ & Halo zone diameter (mm) & Solubilization index (SI) \\
\hline RgoB3.17 & $6.33 \pm 0.58 \mathrm{abc}$ & $10.33 \pm 1.53 \mathrm{de}$ & $2.62 \pm 0.11 \mathrm{cde}$ \\
RMaB2.39 & $7.00 \pm 1.00 \mathrm{ab}$ & $13.33 \pm 1.16 \mathrm{abcd}$ & $2.92 \pm 0.14 \mathrm{bc}$ \\
RLVCB 3 & $6.67 \pm 2.08 \mathrm{abc}$ & $11.67 \pm 3.51 \mathrm{bcd}$ & $2.81 \pm 0.61 \mathrm{bcd}$ \\
RCHVCB1 & $4.67 \pm 0.58 \mathrm{c}$ & $14.67 \pm 1.16 \mathrm{ab}$ & $3.87 \pm 0.12 \mathrm{a}$ \\
RSCB1.50 & $6.67 \pm 2.08 \mathrm{abc}$ & $8.33 \pm 2.31 \mathrm{e}$ & $2.26 \pm 0.12 \mathrm{e}$ \\
RLVCB 2 & $6.00 \pm 1.00 \mathrm{bc}$ & $12.33 \pm 1.53 \mathrm{abcd}$ & $3.07 \pm 0.12 \mathrm{~b}$ \\
RMaB 2.33 & $8.00 \pm 1.00 \mathrm{a}$ & $13.33 \pm 2.08 \mathrm{abcd}$ & $2.66 \pm 0.09 \mathrm{~cd}$ \\
RScB1.19 & $5.33 \pm 0.58 \mathrm{bc}$ & $13.67 \pm 2.08 \mathrm{abc}$ & $3.56 \pm 0.14 \mathrm{a}$ \\
RgoB3.5 & $6.67 \pm 0.58 \mathrm{abc}$ & $11.33 \pm 1.16 \mathrm{cde}$ & $2.70 \pm 0.02 \mathrm{~cd}$ \\
RScB1.7 & $7.67 \pm 1.53 \mathrm{a}$ & $11.33 \pm 1.53 \mathrm{cde}$ & $2.50 \pm 0.15 \mathrm{ed}$ \\
RMaB2 11 & $7.33 \pm 0.58 \mathrm{ab}$ & $15.33 \pm 1.53 \mathrm{a}$ & $3.09 \pm 0.08 \mathrm{~b}$ \\
RMaB1.2 & $6.00 \pm 1.00 \mathrm{abc}$ & $11.00 \pm 1.00 \mathrm{cde}$ & $2.86 \pm 0.30 \mathrm{bc}$ \\
CV & 18.46 & 15.63 & 7.40 \\
Mean & 6.53 & 12.22 & 2.91 \\
T test $(0.05)(\mathrm{LSD})$ & 2.04 & 3.24 & 0.37 \\
\hline
\end{tabular}

Means followed by the same letter (s) in each column are not significantly different at $\mathrm{P} \leq 0.05$.; '+' positive to bromophenole blue," -"Negative

Phosphate solubilizing bacterial isolates, RScB1.19, RCHVCB1 and RMaB2.11 were produced 361.46, 340.37 and $327.32 \mu \mathrm{g} \mathrm{mL}^{-1}$ available $\mathrm{P}$ in the PVK broth after 6 days of incubation time respectively (Table 4).

The $\mathrm{pH}$ value in the uninoculated control flasks remained similar (Table 4). A gradual $\mathrm{pH}$ decrease from the initial 
value of 7.07 to 3.20 on the 6th day was recorded in PVK broth supplemented with tricalcium phosphate (Table 4). Moreover, it was observed that significant $(\mathrm{P} \leq 0.05)$ increments in soluble $\mathrm{P}$ content along with a significant decline in the $\mathrm{pH}$ of the PSB-inoculated medium as evaluated with the control where it remained constant $(\mathrm{pH}-7)$.

The lowest $\mathrm{pH}$ value was recorded ( $\mathrm{pH}-3.20)$ when the quantity of solubilized $\mathrm{P}$ reached the maximum value (361.46 $\mu \mathrm{g} / \mathrm{ml}$ ) and this highest P-solubilizing potential was exhibited by the bacterial strain $\mathrm{RScB} 1.19(361.46 \mu \mathrm{g} / \mathrm{ml})$. The maximum drop in $\mathrm{pH}$ value was significantly coincided with elevated quantity of $\mathrm{P}$ solubilization, where $\mathrm{pH}$ was declined to 3.20 from initial $\mathrm{pH}(\mathrm{pH}-7.07)$ by PSB strain $\mathrm{RScB} 1.19$ (Table 4).

Quantitatively PSB isolates, RScB1.19, RCHVCB1 and RMaB2.11, were produced 361.46, 340.37 and $327.32 \mu \mathrm{g} \mathrm{mL}^{-}$ ${ }^{1}$ soluble P in the PVK broth after 6 days of incubation period, respectively (Table 4). A gradual $\mathrm{pH}$ reduction from the initial value of 7.07 to 3.20 on the $6^{\text {th }}$ day was recorded in PVK broth supplemented with TCP (Table 4). Moreover, it was observed that the amount of solubilized $\mathrm{P}$ increased along with the medium $\mathrm{pH}$ decrease (Table 4). The lowest $\mathrm{pH}$ value was recorded $(\mathrm{pH}-3.20)$ when the amount of solubilized $P$ reached the maximum value $(361.46 \mu \mathrm{g} / \mathrm{ml})$ which exhibited by the bacterial strain RScB1.19 (Table 4).

The 12 superior bacterial isolates were tested for their other phytobeneficial traits such as IAA, $\mathrm{HCN}, \mathrm{NH}_{3}$ production (Figure 3A, B, C) and nitrogen fixing ability and ecophysiological traits (Table 4). Among the isolates RCHVCB1 (gram negative) and RScB1.19 (gram positive) were found to be the best producer of IAA followed by RMaB2.11 and were selected as potential IAA producers (Table 4). On the other hand, the rest 10 isolates were found to be a medium producer of IAA (Table 4). Study on qualitative analysis of $\mathrm{HCN}$ indicated a strong production of $\mathrm{HCN}$ by isolates from soil samples and vermicompost collected in the study area. Accordingly, 9 of the isolates produced $\mathrm{HCN}$ but three isolates were negative for $\mathrm{HCN}$ production (Table 4).

All the 12 isolates produced ammonia (Table 4). Two isolates (RMaB2.39, RLVCB 2) were not able to grow on the $\mathrm{N}$-free medium (Table 4). The rest ten isolates were able to grow on the $\mathrm{N}$-free medium (Table 4).

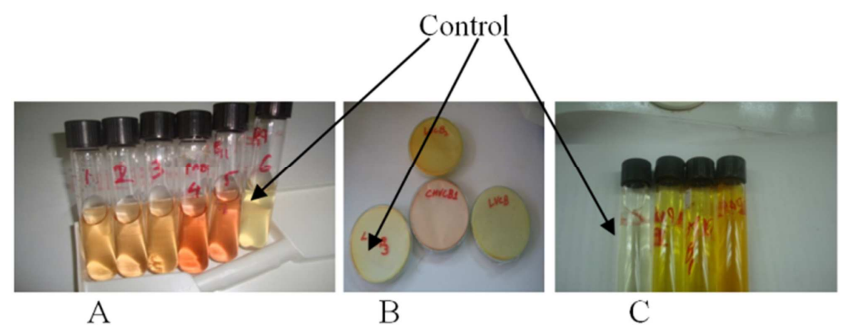

Figure 3. Phytobeneficial traits of bacteria; (a) IAA production, (b) HCN production, (c) $\mathrm{NH}_{3}$ production.

Table 4. Quantitative, pH estimation and PGP traits of phosphate solubilization efficiency of bacterial isolate.

\begin{tabular}{|c|c|c|c|c|c|c|c|}
\hline \multicolumn{4}{|c|}{ Quantitative and pH analysis } & \multicolumn{4}{|c|}{ Phytobeneficial Traits } \\
\hline Isolate code & Incubation period (day) & P-Solublized $(\mu \mathrm{g} / \mathrm{ml})$ & pH after incubation & IAA & $\mathbf{N H}_{3}$ & $\mathrm{HCN}$ & N-Fixing \\
\hline Control & 6 & $0.00 \pm 00 \mathrm{~m}$ & $7.07 \pm 0.06 \mathrm{a}$ & - & - & - & - \\
\hline RgoB3.17 & 6 & $174.22 \pm 0.021$ & $4.44 \pm 0.02 b$ & + & + & + & + \\
\hline RMaB2.39 & 6 & $192.95 \pm 0.02 \mathrm{i}$ & $4.30 \pm 0.01 \mathrm{~d}$ & + & + & - & - \\
\hline RLVCB 3 & 6 & $219.65 \pm 0.01 \mathrm{~h}$ & $4.21 \pm 0.01 \mathrm{e}$ & + & + & ++ & + \\
\hline RCHVCB1 & 6 & $340.37 \pm 0.02 b$ & $3.46 \pm 0.00 \mathrm{j}$ & ++ & + & ++ & + \\
\hline RLVCB 2 & 6 & $228.04 \pm 0.00 \mathrm{~g}$ & $4.18 \pm 0.01 \mathrm{f}$ & + & + & - & - \\
\hline RMaB 2.33 & 6 & $251.53 \pm 0.09 f$ & $4.16 \pm 0.01 \mathrm{f}$ & + & + & + & + \\
\hline $\mathrm{RScB} 1.19$ & 6 & $361.46 \pm 0.01 \mathrm{a}$ & $3.20 \pm 0.00 \mathrm{k}$ & + & ++ & ++ & + \\
\hline RgoB3.5 & 6 & $186.16 \pm 0.01 \mathrm{j}$ & $4.36 \pm 0.01 \mathrm{c}$ & + & + & + & + \\
\hline $\mathrm{RScB} 1.7$ & 6 & $271.21 \pm 0.01 \mathrm{~d}$ & $3.85 \pm 0.01 \mathrm{~h}$ & + & + & + & + \\
\hline RMaB2.11 & 6 & $327.32 \pm 0.01 \mathrm{c}$ & $3.76 \pm 0.01 \mathrm{i}$ & ++ & + & ++ & + \\
\hline $\mathrm{CV}$ & & 0.01 & 0.41 & & & & \\
\hline Mean & & 230.28 & 4.26 & & & & \\
\hline T test $(0.05)$ (LSD) & & 0.02 & 0.03 & & & & \\
\hline
\end{tabular}

* Means followed by the same letter (s) in each column are not significantly different at $\mathrm{P} \leq 0.05$

\subsection{Ecophysiological Traits}

\subsubsection{Tolerance to Heavy Metals}

The 12 PSB isolates resisted heavy metals such as $\mathrm{Hg}, \mathrm{Cu}$, $\mathrm{Zn}$ and $\mathrm{Mn}$, up to $400 \mu \mathrm{g} / \mathrm{ml}$ at varying degree (Tables 5 and $6)$. The results showed that most of the PSB isolates grew well at low concentrations of heavy metals studied and their number drastically decreased as the concentration of Mercury
$(\mathrm{Hg})$, Copper $(\mathrm{Cu})$ and Manganese $(\mathrm{Mn})$ increased. In Zinc (Zn) medium, all the PSB isolates were able to grow at concentrations of 100-300 $\mu \mathrm{g} / \mathrm{ml}$, except at concentration 400 $\mu \mathrm{g} / \mathrm{ml}$. Among the twelve PSB isolates, RCHVCB 1 , RScB1.19 and RMaB2.11 showed high tolerance to all the tested heavy metals (Table 6). 
Table 5. Numbers of heavy metal tolerant PSB at different concentrations of tested heavy Metals. Values in parenthesis indicated \% of heavy metal tolerant isolates.

\begin{tabular}{lllll}
\hline $\begin{array}{l}\text { Heavy metals concentration } \\
(\boldsymbol{\mu g} / \mathbf{m l})\end{array}$ & Heavy metals & & & \\
\cline { 2 - 5 } & Mercury $\left(\mathbf{H g C l}_{\mathbf{2}}\right)$ & $\mathbf{C o p p e r}\left(\mathbf{C u C l}_{\mathbf{2}}\right)$ & Manganese $(\mathbf{M n C l})$ & $\mathbf{Z i n c}(\mathbf{Z n C l} \mathbf{)}$ \\
\hline 100 & $11(91.67)$ & $9(75.00)$ & $11(91.67)$ & $12(100)$ \\
200 & $11(91.67)$ & $7(58.33)$ & $9(75.00)$ & $12(100)$ \\
300 & $8(66.67)$ & $6(50.00)$ & $7(58.33)$ & $12(100)$ \\
400 & $4(33.33)$ & $7(50.00)$ & $4(33.33)$ & $11(91.67)$ \\
\hline
\end{tabular}

Table 6. Heavy metal tolerant PS bacterial isolates at different concentrations.

\begin{tabular}{|c|c|c|c|c|c|c|c|c|c|c|c|c|c|c|c|c|}
\hline \multirow{3}{*}{ Isolate No } & \multicolumn{16}{|c|}{ Heavy metals $(\mu \mathrm{g} / \mathrm{ml})$} \\
\hline & \multicolumn{4}{|c|}{ Mercury $\left(\mathrm{HgCl}_{2}\right)$} & \multicolumn{4}{|c|}{ Copper $\left(\mathrm{CuCl}_{2}\right)$} & \multicolumn{4}{|c|}{ Manganese $\left(\mathrm{MnCl}_{2}\right)$} & \multicolumn{4}{|c|}{ Zinc $\left(\mathrm{ZnCl}_{2}\right)$} \\
\hline & 100 & 200 & 300 & 400 & 100 & 200 & 300 & 400 & 100 & 200 & 300 & 400 & 100 & 200 & 300 & 400 \\
\hline RgoB3.17 & + & + & + & - & + & + & - & - & + & + & + & - & + & + & + & + \\
\hline RMaB2.39 & + & + & + & - & - & - & - & - & + & + & + & + & + & + & + & + \\
\hline RLVCB 3 & + & + & + & - & + & - & - & - & + & + & - & - & + & + & + & + \\
\hline RCHVCB1 & + & + & + & + & + & + & + & + & + & + & + & + & + & + & + & + \\
\hline RSCB1.50 & + & + & + & + & + & + & + & + & + & + & + & + & + & + & + & + \\
\hline RLVCB 2 & + & + & - & - & - & - & - & - & + & + & - & - & + & + & + & + \\
\hline RMaB 2.33 & + & + & - & - & + & + & + & + & + & - & - & - & + & + & + & + \\
\hline RScB1.19 & + & + & + & - & + & + & + & + & + & + & + & - & + & + & + & + \\
\hline RgoB3.5 & + & + & - & - & + & - & - & - & + & - & - & - & + & + & + & + \\
\hline $\mathrm{RScB} 1.7$ & + & + & + & + & + & + & + & + & + & + & + & + & + & + & + & + \\
\hline RMaB2.11 & + & + & + & + & + & + & + & + & + & + & + & - & + & + & + & + \\
\hline RMaB1.2 & - & - & - & - & - & - & - & - & + & - & - & - & + & + & + & - \\
\hline
\end{tabular}

“+” resistant, "-" sensitive

\subsubsection{Tolerance to Salinity and $\mathrm{pH}$}

The results showed that most of the PSB isolates grew well at concentrations of $3 \%, 4 \%$ and $5 \% \mathrm{NaCl}$ (Table 7). However, no growth was observed as the concentration of $\mathrm{NaCl}$ increased from $6 \%$ to $7 \%$ (Table 7). The interaction effect between isolates and $\mathrm{NaCl}$ concentrations was found to be effective. Generally, as the concentration of $\mathrm{NaCl}$ increased beyond 5\%, growth decreased abruptly (Table 7). Moreover, the majority of the isolates tolerated $\mathrm{pH}$ in the range of 5 to 8 except isolates RSCB1.50, RScB1.19 and RMaB2.11, because they showed tolerance to $\mathrm{pH}-4$. Some isolates, RCHVCB1 and RLVCB2, were able to tolerate $\mathrm{pH}$ up to 9 (Table 7).

Table 7. Evaluation of the isolate to salinity and $\mathrm{pH}$.

\begin{tabular}{|c|c|c|c|c|c|c|c|c|c|c|c|c|}
\hline \multirow{2}{*}{ Isolate code } & \multicolumn{5}{|c|}{ Concentrations of $\mathrm{NaCl}(\mathrm{w} / \mathrm{v})$} & \multicolumn{7}{|c|}{ Acid tolerance (pH) } \\
\hline & $3 \%$ & $4 \%$ & $5 \%$ & $6 \%$ & $7 \%$ & 4 & 5 & 6 & 7 & 8 & 9 & 10 \\
\hline RgoB3.17 & + & + & + & - & - & - & + & + & + & + & - & - \\
\hline RMaB2.39 & + & + & + & - & - & - & + & + & + & + & - & - \\
\hline RLVCB 3 & + & + & + & - & - & - & + & + & + & + & - & - \\
\hline RCHVCB1 & + & + & + & + & - & - & + & + & + & + & + & - \\
\hline RSCB1.50 & + & + & + & - & - & + & + & + & + & + & - & - \\
\hline RLVCB 2 & + & + & + & - & - & - & + & + & + & + & + & - \\
\hline RMaB 2.33 & + & + & + & - & - & - & + & + & + & + & - & - \\
\hline RScB1.19 & + & + & + & - & - & + & + & + & + & + & - & - \\
\hline RgoB3.5 & + & + & + & - & - & - & + & + & + & + & - & - \\
\hline RScB1.7 & + & + & + & - & - & - & + & + & + & + & - & - \\
\hline RMaB2.11 & + & + & + & - & - & + & + & + & + & + & - & - \\
\hline RMaB1.2 & + & + & + & - & - & - & + & + & + & + & - & - \\
\hline
\end{tabular}

"+" indicates presence of growth "-" indicates absence of growth 
Table 8. Qualitative and quantitative estimation of phosphate solubilized by fungal strains.

\begin{tabular}{llll}
\hline Qualitative analysis & & & \\
\hline Isolate code & Colony diameter $(\mathbf{m m})$ & Halo zone diameter $(\mathbf{m m})$ & Solublizationindex $($ SI) \\
\hline RCDVCF4 & $43.33 \pm 1.53 \mathrm{abc}$ & $90 \pm 0.00 \mathrm{a}$ & $3.08 \pm 0.07094599 \mathrm{bc}$ \\
RLVCF2 & $45.00 \pm 0.00 \mathrm{ab}$ & $90 \pm 0.00 \mathrm{a}$ & $3.03 \pm 0.05 \mathrm{bc}$ \\
RCHVCF3 & $42.33 \pm 2.08 \mathrm{bc}$ & $90 \pm 0.00 \mathrm{a}$ & $3.10 \pm 0.13 \mathrm{bc}$ \\
RCHVCF2 & $43.33 \pm 2.89 \mathrm{abc}$ & $90 \pm 0.00 \mathrm{a}$ & $3.08 \pm 0.14 \mathrm{bc}$ \\
RCHVCF1 & $95.00 \pm 0.00 \mathrm{ab}$ & $90 \pm 0.00 \mathrm{a}$ & $3.00 \pm 0.00 \mathrm{c}$ \\
RLVCF1 & $41.33 \pm 3.22 \mathrm{c}$ & $90 \pm 0.00 \mathrm{a}$ & $3.19 \pm 0.16 \mathrm{~b}$ \\
R CHVC F4 & $37.67 \pm 2.52 \mathrm{~d}$ & $90 \pm 0.00 \mathrm{a}$ & $3.40 \pm 0.16 \mathrm{a}$ \\
RSCF1.19 & $46.00 \pm 1.73 \mathrm{a}$ & $90 \pm 0.00 \mathrm{a}$ & $2.96 \pm 0.07 \mathrm{c}$ \\
RMaF2.35 & $44.00 \pm 1.00 \mathrm{abc}$ & 0.00 & $3.05 \pm 0.05 \mathrm{bc}$ \\
CV & 4.798 & 90.00 & 3.45 \\
Mean & 43.11 & 0.00 & 3.10 \\
T test (0.05) (LSD) & 3.58 & & 0.19 \\
\hline
\end{tabular}

* Means followed by the same letter (s) in each column are not significantly different at $\mathrm{P} \leq 0.05$

\subsection{Qualitative and Quantitative Estimations of Phosphate Solubilization by Fungi}

All the 9 fungi tested were able to solubilize the inorganic TCP at sixth days of incubation, showing strong average mean halo zone formation (mean $\mathrm{SI}=2.91$ ) with a little variation in average mean colony diameter (Table 8 ).

The phosphate solubilization potential of the 9 fungal isolates ranged between $180.26 \pm 0.01$ to $360.48 \pm 10.05 \mu \mathrm{g} / \mathrm{ml}$ (Table 9). Among all the nine PSF, the fungal isolate, RSCF1.19, was found to be the best solubilizer of TCP $(360.48 \pm 10.05 \mu \mathrm{g} / \mathrm{ml})$. Overall, RSCF1.19, RCHVCF 2 and $\mathrm{RLVCF}_{2}$ were found to be the best fungal solubilizers (Table 9).

Table 9. Quantitative estimation of phosphate solubilized by fungal strains

\begin{tabular}{llll}
\hline Quantitative and pH estimation & & \\
\hline Isolate code & $\begin{array}{l}\text { Incubation } \\
\text { period }(\mathbf{d a y})\end{array}$ & $\begin{array}{l}\text { P-Solublized } \\
(\boldsymbol{\mu g} / \mathbf{m l})\end{array}$ & $\begin{array}{l}\mathbf{p H} \text { after } \\
\text { incubation }\end{array}$ \\
\hline Control & 15 & $7.02 \pm 0.06 \mathrm{a}$ & $7.07 \pm 0.06 \mathrm{a}$ \\
RCDVCF4 & 15 & $180.26 \pm 0.01 \mathrm{i}$ & $4.44 \pm 0.01 \mathrm{~b}$ \\
RLVCF2 & 15 & $327.32 \pm 0.01 \mathrm{c}$ & $3.76 \pm 0.01 \mathrm{~g}$ \\
RCHVCF3 & 15 & $219.65 \pm 0.01 \mathrm{~g}$ & $4.21 \pm 0.01 \mathrm{ed}$ \\
RCHVCF2 & 15 & $340.37 \pm 0.02 \mathrm{~b}$ & $3.46 \pm 0.00 \mathrm{~h}$ \\
RCHVCF1 & 15 & $260.51 \pm 0.01 \mathrm{~d}$ & $3.98 \pm 0.02 \mathrm{f}$ \\
RLVCF1 & 15 & $228.04 \pm 0.00 \mathrm{f}$ & $4.29 \pm 0.12 \mathrm{~cd}$ \\
R CHVC F4 & 15 & $251.53 \pm 0.03 \mathrm{e}$ & $4.16 \pm 0.01 \mathrm{e}$ \\
RSCF1.19 & 15 & $360.48 \pm 10.05 \mathrm{a}$ & $3.20 \pm 0.10 \mathrm{i}$ \\
RMaF2.35 & 15 & $186.16 \pm 0.01 \mathrm{~h}$ & $4.36 \pm 0.01 \mathrm{bc}$ \\
CV & 15 & 1.35 & 1.26 \\
Mean & & 235.43 & 4.29 \\
T test (0.05) (LSD) & & 5.44 & 0.09 \\
\hline
\end{tabular}

* Means followed by the same letter (s) in each column are not significantly different at $\mathrm{P} \leq 0.05$

\subsection{Characterization and Identification of Isolates}

Based on their phytobeneficial and ecophysiological trait profiles, the three superior bacterial isolates; $\mathrm{RCHVCB}_{1}$,
RScB1.19 and RMaB2.11 were selected for the seed germination assay and subjected to be characterized and identified biochemically. The results revealed that among the three isolates two of them (RScB1.19 and RMaB2.11) were negative for gelatin liquefaction, and positive for oxidase test, catalase, and starch hydrolysis (Table 10). Similarly, these two isolates were negative for sucrose utilization and positive for utilization of galactose, lactose and glucose (Table 10).

Among the total of 72 isolates of coffee rhizosphere and VC samples, 9 fungal isolates were showed clearly visible large halo zones around their colonies with different diameter on PVK agar medium after 6 days of incubation. The code numbers given to the nine (9) fungal isolates and their respective identification are as follows: RCDVCF4 (Aspergillus sp.), RLVCF2 (Aspergillus sp.), RCHVCF3 (Aspergillus sp.), RCHVCF3 (Aspergillus sp.), RCHVCF2 (Aspergillus sp.), RCHVCF1 (Aspergillus sp.), RLVCF1 (Aspergillus sp.), RCHVCF4 (Aspergillus sp.), (Aspergillus sp), RSCF1.19, (Penicillium sp.) and RMaF2.35 (Aspergillus $s p$.). The morphological characteristics of the hyphae, spores, and conidiophores of the PSF were examined by optical microscopic. RSCF1.19 presented typical penicillate conidiophores with conidia (Figure 4B), whereas Aspergillus group produced typical double spore production cells, which were identified as the black conidia in conidiophores and represented Aspergillus sp (Figure 4A).

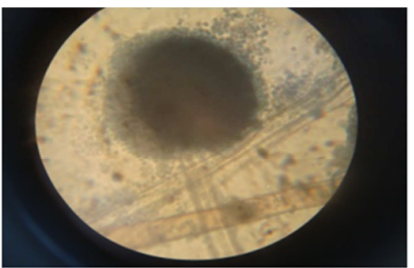

(A)

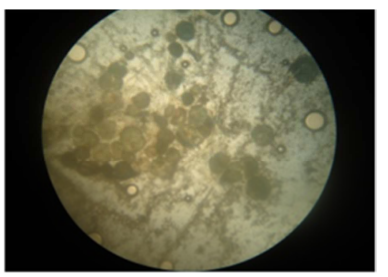

(B)
Figure 4. Morphological characters (A) Conidia (Aspergillus spp) (B) Conidia (Penicilium sp). 
Table 10. Morphological and biochemical characteristics of phosphate solubilizing bacterial isolates.

\begin{tabular}{llll}
\hline Characteristics & Bacterial isolates & & \\
\hline & RCHVCB 1 & RScB1.19 & RaB2.11 \\
Cultural and Morphological & Rod shaped & Rod shaped & Rod shaped \\
Characteristics & Gram -ve & Gram +ve, & Gram +ve, \\
& Yellowish green Colony color & Creamy white Colony color & Creamy white Colony color \\
Motility test & Oval colony shape & Circular colony shape & Circular colony shape \\
Bacterial growth at $5 \% \mathrm{NaCl}$ & + & + & + \\
Catalase test & + & + & + \\
Oxidase test & + & + & + \\
Gelatin hydrolysis & + & + & + \\
Starch hydrolysis & + & - & + \\
Nitrate reduction & - & + & + \\
Galactose & + & + & + \\
Glucose & - & + & + \\
Lactose & + & + & + \\
sucrose & - & + & - \\
\hline
\end{tabular}

\subsection{Effect of Isolates on Coffee Seed Germination}

The Highly effective PSB ( $\mathrm{n}=3$ ) and fungal isolates $(\mathrm{n}=3)$ affected the germination of coffee seeds remarkably (Table 11). Germination rates and vigor index was calculated for all inoculation treatments (Table 11). In almost all the treatments RScB1.19 + RSCF1.19, RMaB2.11 + RCHVCF2, RMaB2.11 + RLVCF2, RCHVCB $_{1}+\mathrm{RSCF}_{1.19}, \mathrm{RCHVCB}_{1}$, $\mathrm{RScB} 1.19$ and RSCF1.19 isolates increased seed germination index over untreated seeds (Table 11).

Table 11. Results of germination rate and Vigor Index (VI).

\begin{tabular}{|c|c|c|c|c|c|}
\hline \multicolumn{2}{|c|}{ Treatments } & \multirow{2}{*}{$\begin{array}{l}\text { Germination rate }(\%) \\
23.33 \mathrm{ab}\end{array}$} & \multirow{2}{*}{$\begin{array}{l}\text { Mean Root Length (cm) } \\
1.50 \mathrm{ab}\end{array}$} & \multirow{2}{*}{$\begin{array}{l}\text { Mean Shoot Length (cm) } \\
1.83 \mathrm{ab}\end{array}$} & \multirow{2}{*}{$\begin{array}{l}\text { Vigor index } \\
77.69\end{array}$} \\
\hline T1 & RCHVCB1 & & & & \\
\hline $\mathrm{T} 2$ & RScB1.19 & $30.00 \mathrm{a}$ & $1.17 \mathrm{ab}$ & $1.33 \mathrm{bcd}$ & 75.00 \\
\hline T3 & RMaB2.11 & $23.33 \mathrm{ab}$ & $1.00 \mathrm{~b}$ & $1.23 \mathrm{~cd}$ & 52.03 \\
\hline T4 & RSCF1.19 & $23.33 \mathrm{ab}$ & $1.47 \mathrm{ab}$ & $2.00 \mathrm{a}$ & 80.96 \\
\hline T5 & RCHVCF2 & $16.67 \mathrm{ab}$ & $1.30 \mathrm{ab}$ & $1.67 \mathrm{abcd}$ & 49.45 \\
\hline T6 & RLVCF2 & $23.33 \mathrm{ab}$ & $1.83 \mathrm{a}$ & $1.33 \mathrm{bcd}$ & 42.17 \\
\hline $\mathrm{T} 7$ & RCHVCB1+ RSCF1.19 & $26.67 \mathrm{ab}$ & $1.50 \mathrm{ab}$ & $1.23 \mathrm{~cd}$ & 72.81 \\
\hline T8 & RCHVCB1+ RCHVCF2 & $16.67 \mathrm{ab}$ & $0.93 b$ & $1.23 \mathrm{~cd}$ & 36.01 \\
\hline T9 & RCHVCB1+ RCHVCF2 & $16.67 \mathrm{ab}$ & $1.33 \mathrm{ab}$ & $1.53 \mathrm{abcd}$ & 47.73 \\
\hline T10 & RScB1.19+ RSCF1.19 & $26.67 \mathrm{ab}$ & $1.33 \mathrm{ab}$ & $1.67 \mathrm{abcd}$ & 80.01 \\
\hline T11 & RScB1.19 + RCHVCF2 & $13.33 \mathrm{ab}$ & $1.17 \mathrm{ab}$ & $1.17 \mathrm{~d}$ & 31.10 \\
\hline T12 & RScB1.19 + RLVCF2 & $10.00 \mathrm{~b}$ & $1.17 \mathrm{ab}$ & $1.67 \mathrm{abcd}$ & 28.37 \\
\hline T13 & RMaB2.11 + RSCF1.19 & $16.67 \mathrm{ab}$ & $1.17 \mathrm{ab}$ & $1.33 \mathrm{bcd}$ & 41.73 \\
\hline T14 & RMaB2.11 + RCHVCF2 & $30.00 \mathrm{a}$ & $1.50 \mathrm{ab}$ & $1.50 \mathrm{abcd}$ & 90.00 \\
\hline $\mathrm{T} 15$ & RMaB2.11 + RLVCF2 & $30.00 \mathrm{a}$ & $1.83 \mathrm{a}$ & $1.50 \mathrm{abcd}$ & 99.90 \\
\hline T16 & -Ve control & $13.33 \mathrm{ab}$ & $1.00 \mathrm{~b}$ & $1.17 \mathrm{~d}$ & 28.88 \\
\hline $\mathrm{CV}$ & & 51.27 & 33.46 & 21.41 & \\
\hline Mea & & 20.59 & 1.31 & 1.48 & \\
\hline $\mathrm{T}$ tes & 5) (LSD) & 17.55 & 0.73 & 0.53 & \\
\hline
\end{tabular}

* Means followed by the same letter (s) in each column are not significantly different at $\mathrm{P} \leq 0.05$

\section{Discussion}

On the basis of morphological and biochemical characteristics of the phosphate solubilizing efficacy, three bacterial isolates $\left(\mathrm{RCHVCB}_{1}, \mathrm{RScB} 1.19\right.$ and $\left.\mathrm{RMaB} 2.11\right)$ were identified at genus level and selected for the seed germination assay. The results obtained are consistent with the many phenotypic characteristics of the genera Bacillus and Pseudomonas. The results revealed that among the three isolates, two of them (RScB1.19 and RMaB2.11) were Bacillus species but one isolate identified as Pseudomonas sp. ( $\left.\mathrm{RCHVCB}_{1}\right)$. Accordingly, Babu et al [42] have isolated both Bacillus and Pseudomonas from maize rhizosperic soils samples using morphological and biochemical parameters. The present findings are consistent with the finding of Dhurve et al. [43] who verified the ability of Pseudomonas isolates to produce $\mathrm{H}_{2} \mathrm{~S}$ gas, liquefy gelatin but failed to hydrolyse starch. Moreover, our findings are in line with reports of Karpagam and Nagalakshmi [44], who characterized and identified Bacillus spp. based on their Vogues Proskauer test, Citrate utilization, nitrate reduction, gelatin hydrolysis, lactose and mannitol fermentation but did not produce $\mathrm{H}_{2} \mathrm{~S}$ gas.

Phosphate solubilization results recorded in liquid medium showed that all the isolates had the potential to solubilize the inorganic form of $\mathrm{P}$ as indicated by a gradual increase in the 
amount of soluble $\mathrm{P}$ in the medium. The highest decrease in $\mathrm{pH}$ value was related to high levels of $\mathrm{P}$ released by PSB isolate $\mathrm{RScB} 1.19$, while the $\mathrm{pH}$ was dropped to 3.2 from initial $\mathrm{pH}-7$. Our result was similar to the earlier findings which indicated that available $\mathrm{P}$ released from $\mathrm{Ca}_{3}\left(\mathrm{PO}_{4}\right)_{2}$ by 3 strains of Bacillus megaterium and Pseudomonas fluorescens ranged from 427.7 to $489.4 \mathrm{mg} \mathrm{l}^{-1}$ and the $\mathrm{pH}$ values of the cultures were reduced from 7 to values between 4 and 4.4 [45].

The decline in $\mathrm{pH}$ might indicate the production of organic acid, which suggests that acidification of the culture supernatant, might be the principal mechanism for phosphate solubilization $[8,46]$. Efficient $\mathrm{P}$ solubilizers are known to lower the $\mathrm{pH}$ of plant growing medium in which the microbes are establishing themselves [47]. Phosphate solubilizing rhizobacteria exhibited diverse phytobeneficial triats. Accordingly, most of the rhizobacteria associated with coffee rhizosphere and vermicompost produced indole acetic acid detected qualitatively.

A characteristic pressure of Rhizobacteria in the soil environment is a release of auxin phyto-hormones to make available nutrients in the soil [48]. Mohite, [49] described that IAA producing rhizosphere isolates were significantly increased the plant height and root length of wheat seedlings along with increased in chlorophyll content compared to the control. Moreover, IAA enables the rhizo-bacteria to adapt and resist the high concentrations of heavy metals through activation of physiological changes in plant cell metabolism under metal stress (Glick 2010). Moreover, an increased in root length because of IAA, was reported in Brassica campestris plants due to inoculation with Pseudomonas and Azotobacter spp [50]. Production of high level of IAA by bacterial isolates has a direct influence on plant growth as they increase plant root length [51]. Hence the test isolates were extremely promising in enhancing root growth for the vigor of plant establishment and increased yield production.

In the present study, most of the isolates produced $\mathrm{HCN}$ under in vitro conditions and they are promising in the plant growth promotion as reported in the previous study [52]. An investigation was conducted on the production of $\mathrm{HCN}$ by $P$. fluorescens to control root rot of ground nut due to $M$. phaseolina with strong suppression of the pathogen [53]. Moreover, Ramette et al., [54] have reported that growth of causative agent of black root rot of tobacco was suppressed due to released HCN in the rhizosphere by Pseudomonas sp. Ahmad et al, [55] have also documented accumulation of HCN by Pseudomonas and Bacillus spp. in nodule forming plant rhizosphere.

All of our isolates were able to produce ammonia and this phytobeneficial trait can effect indirectly plants growth. Our result was in line with reports of Ahmed et al. [55] who found that release of ammonia by all the isolates of Pseudomonas and Bacillus spp.

Among the phosphate solublizers, ten isolates including both Bacillus species and Pseudomonas species (83.33\%) were able to grow on the $\mathrm{N}$-free media. This result is consistent with the findings of Muthukumarasamy et al [56] who confirmed the existence of $\mathrm{N}$-fixation among the genera of Bacillus and Pseudomonas.

In the present study, some of the potent isolates exhibited enhanced tolerance to various potentially toxic heavy metals. He et al. [57] described that rhizosphere bacteria such as Bacillus sp. and Pseudomonas sp. are very promising agents due to their solubilization of insoluble and biologically unavailable $\mathrm{Zn}$ by secreting low molecular weight organic acids. Madhaiyan et al. [58] have also added an isolates obtained from coffee plantation that could solubilize insoluble $\mathrm{Zn}_{3}\left(\mathrm{PO}_{4}\right)_{2}$. Our results also support the idea that these groups of soil bacteria play a pivotal role in monitoring the possible impact of heavy metal contamination by making it bio-available to plants.

Among our isolates, RCHVCB1 showed growth on maximum concentration of $\mathrm{NaCl}(6 \%)$ and was superior to other isolates. This bacterium was isolated from the vermicompost having $\mathrm{pH} 9.5$ (Table 1). Tolerance towards high salinity and $\mathrm{pH}$ could be important traits for rhizobacteria in a competitive rhizosphere for multiplication, survival and spread in alkaline soils.

The three phosphate solublizing fungi (RSCF1.19, $\mathrm{RCHVCF}_{2}$ and $\mathrm{RLVCF}_{2}$ ) were isolated from the coffee rhizosphere in acidic soils and alkaline vermicompost. Similarly, the qualitative estimations performed through agar based bioassays showed a clear halo zone around the fungal colony [59]. Rinu and Pandey [60] demonstrated a decline in $\mathrm{pH}$ was in a parallel increment with fungal phosphate solubilizeation tendency. The $\mathrm{pH}$ of the fermentation broth of the nine PSF generally changed with the increasing initial $\mathrm{pH}$

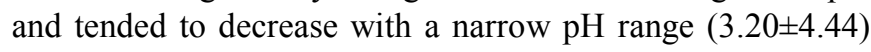
from the initial $\mathrm{pH}(7.02 \pm 0.06)$. This result could show that organic acids were secreted by all the nine PSF with different degrees [61]. The finding of the phosphate solubilization of the three fungal isolates (RSCF1.19, RCHVCF2 and RLVCF2) for the TCP clearly indicated an optimum and efficient solubilization potential of TCP [62].

RSCF1.19 showed more $P$ accumulation $(360.48 \pm 10.05 \mu \mathrm{g} / \mathrm{ml})$ with $\mathrm{pH}$ range of $3.20 \pm 4.44$ compared to other eight PSF which may be explained by the finding that the solubilization of the $\mathrm{P}$ mostly dependent on the amount of acids production [63].

The lower $\mathrm{pH}$ (3.20) by isolate RSCF1.19 may be attributed to the higher production of organic acids compared to the rest nine PSF [64]. A. niger and A. flavus have been studied as TCP solubilizers by several researchers whose investigations are in agreement with our findings [65]. Several strains of PSMs solubilize TCP to make it available to plants.

Based on the current investigation, these three fungal isolates (RSCF1.19, RCHVCF2 and RLVCF2) that showed substantial qualitative and quantitative inorganic phosphate solublization was chosen to be tested for seed germination under laboratory condition.

Bacterial and fungal phosphate solublizers, which can solubilize insoluble phosphate compounds by producing organic acids and/or phosphatase enzymes to improve $\mathrm{P}$ 
availability in soils [66] can stimulate growth and mineral uptake of plants. Consistently, our results with others findings suggest that selection and integration of the most efficient bacterial and fungal $\mathrm{P}$ solublizers as bio-inoculants with chemical phosphate fertilizer can improve crop mineral nutrients in nutrient-deficient soils. In this regards, three bacterial and three fungal isolates were selected for germination assay. In our investigation, a significant variation in seed germination rate and root and shoot lengths of coffee seedlings were observed in response to different PSB and fungal isolates. In general, all the isolates showed better performance with respect to seed germination and growth of seedlings. Inoculation results revealed that root and shoot lengths were significantly increased when treated with RLVCF2 and RSCF1.19 over uninoculated control, respectively. Moreover, co-inoculation of RMaB2.11 with RLVCF2 (RMaB2.11+ RLVCF2) was also significantly increased root length over uninoculated control. Results showed that both RSCF1.19 and RLVCF2 (Fungal) isolates took the highest level over bacterial inoculants in coffee seed germination and vigor index as well as root and shoot elongation. Bertrand et al. [67] was also reported a similar findings that increased root length due to microbial intervention during root propagation. However, except in coinoculation of RScB1.19 with RLVCF2 (RScB1.19+ RLVCF2), both bacterial and fungal isolates were not shown significant variation in germination rate over the control. Both co-inoculation and single inoculation of bacteria and fungi (RScB1.19+ RSCF1.19, RMaB2.11+ RCHVCF2, RMaB2.11+ RLVCF2, RCHVCB1+ RSCF1.19, RCHVCB1, RScB1.19, and RSCF1.19) showed better performance with respect to vigor index. In germination assay, coffee seedlings growth (root, shoot and vigour index) was improved [68]. Likewise, PGPR enhanced the growth and germination of seeds in pot under natural condition [69]. A large body of evidence suggests that phosphate solublizing microorganisms enhance the growth, seed emergence and crop yield, and contribute to the protection of plants against certain pathogens and pests [70]. On the basis of these findings, it can be assumed that the future microbial phosphate solublizers are the best alternative to chemical fertilizers and pesticides. Therefore, it was concluded that the bacterial and fungal isolates such as RSCF1.19, RCHVCF2, RLVCF2, RCHVCB1, RScB1.19 and $\mathrm{RMaB} 2.11$, can be used as inoculants for development of efficient biofertilizer for field application in cultivation of Coffea arabica in sustainable agriculture.

\section{Conclusion}

Some of the potent isolates exhibited plant growth promoting attributes such as indole acetic acid (IAA), hydrogen cyanide production $(\mathrm{HCN})$, ammonia $\left(\mathrm{NH}_{3}\right)$ production and inherent nitrogen fixing capacity and adaptation to different ecophysiological traits such as heavy metals, saline soils and acidic soils. This study also revealed that wide varieties of phosphate solubilizing fungi are present in the vicinity of coffee plants and vermicompost but the dominant strains are Aspergillus and Penicillium. Penicillium spp can be used as potential biofertilizers for promoting growth of coffee plants because of its higher solubilization efficiency of TCP. In the present study, the efficient bacterial and fungal isolates showed significant variation in germination rates over control. Both co-inoculation and single inoculation of bacteria and fungi (RScB1.19+ RSCF1.19, RMaB2.11+ RCHVCF2, RMaB2.11+ RLVCF2, RCHVCB1+ RSCF1.19, RCHVCB1, RScB1.19, and RSCF1.19) showed better performance with respect to seed germination and vigor index. Therefore, these selected PSF and bacteria should be investigated in detail for field application in coffee production for its potential as biofertilizer agents in sustainable low inputs agriculture.

\section{Conflict of Interest}

The authors declare that they have no competing interests.

\section{Acknowledgements}

This work was supported by Ethiopian Institute of Agricultural Research and Agricultural Growth Program Component II (AGP II) in financing the work of our studies. We would like to thank Jimma University, School of veterinary medicine for their assistance and support in laboratory facilities.

\section{References}

[1] Bhat, S. A., Singh, J., Vig, A. P. (2017) Earthworms as organic waste managers and Biofertilizer producers. Waste Biomass Valoriz. http://dx.doi.org/10.1007/s12649-017-9899-8.

[2] Richardson AE. and Simpson, RJ. (2011). Soil microorganisms mediating phosphorus availability. Plant Physiol 156: 989-996.

[3] Koch, M. Kruse, J., Eichler-Löbermann, E., Zimmer, D., Willbold, S., Leinweber, P., Siebers, N. (2018). Phosphorus stocks and speciation in soil profiles of a long-term fertilizer experiment: evidence from sequential fractionation, $\mathrm{P}$ K-edge XANES, and 31P NMR spectroscopy. Geoderma 316: 115126.

[4] Sharma P, Padh H, Shrivastava N (2013). Hairy root cultures: a suitable biological system for studying secondary metabolic pathways in plants. Eng Life Sci 13: 62-75.

[5] Chung H, Park M, MadhaiyanaM, Seshadri S, Song J, Cho H and Sa T (2005) Isolation and characterization of phosphate solubilizing bacteria from the rhizosphere of crop plants of Korea. Soil Biol Biochem 3: 1970-1974.

[6] Rodríguez H and Fraga R (1999) Phosphate solubilizing bacteria and their role in plant growth promotion. Biotechnol Adv 17: 319-339.

[7] Souza R, Beneduzi A, Ambrosini A, Costa PB, Meyer J, Vargas LK, Schoenfeld R and Passaglia LMP (2013). The effect of plant growth-promoting rhizobacteria on the growth of rice (Oryza sativa L.) cropped in southern Brazilian fields. Plant Soil 366: 585-603. 
[8] Chen, Y. P., Rekha, P. D., Arun, A. B., Shen, F. T., Lai, W. A., Young, C. C., (2006). Phosphate solubilizing bacteria from subtrophical soil and their Tricalcium phosphate solubilizing abilities. Appl. Soil Ecol. 34, 33-41.

[9] Suhane RK (2007). Vermicompost. Publication of Rajendra Agriculture University, Pusa, 88.

[10] Biswas, J. K., Banerjee, A Rai, M. Ravi Naidu, R., Biswas, B., Vithanage, M., Dash, M. C., Sarkar, S. K., Erik Meers, E., (2018) Potential application of selected metal resistant phosphate solubilizing bacteria isolated from the gut of earthworm (Metaphire posthuma) in plant growth promotion. Elsevier B. V. Geoderma 330: 117-124.

[11] Esakkiammal B., Esaivani C., Vasanthi K, LakshmiBai L. and Shanthi Preya N. (2015) Microbial diversity of Vermicompost and Veriwash prepared from Eudrilus euginae. Int. J. Curr. Microbiol. App. Sci. 4 (9): 873-883.

[12] Anastasi, A., Varese, C. G., Marchisio F. V. (2005). Isolation and identification of fungal communities in compost and vermicompost. Mycologia, 97 (1), pp. 33-44.

[13] Chuang, C.-C., Kuo, Y.-L., Chao, C.-C. and Chao, W.-L. (2007). Solubilization of inorganic phosphates and plant growth promotion by Aspergillus niger, Biology \& Fertility of Soils, vol. 43, no. 5, pp. 575-584.

[14] Fankem, H., Nwaga. D., Deubel, A., Dieng, L., Merbach, W. and Etoa, F. X., (2006). Occurrence and functioning of phosphate solubilizing microorganisms from oil palm tree (Elaeisguineensis) rhizosphere in Cameroon. African Journal of Biotechnology, 5: 2450-2460.

[15] Gaind, S. (2016). Phosphate dissolving fungi: Mechanism and application in alleviation of salt stress in wheat, Microbiological Research 193: 94-102.

[16] Pandey, A., Das, N., Kumar, B., Rinu, K. and Trivedi, P. (2008). Phosphate solubilization by Penicillium spp. isolated from soil samples of Indian Himalayan region, World Journal of Microbiology \& Biotechnology, vol. 24, no. 1, pp. 97-102.

[17] Pindi PK, Satyanarayana SDV. (2012). Liquid microbial consortium- a potential tool for sustainable soil health. J Biofertil Biopest, 3: 4

[18] Zaharan, H. (1999). Rhizobium-legume symbiosis and nitrogen fixation under severe conditions and in an arid climate. Microbiology and Molecular Reviews, 63: 968-989.

[19] Muleta, D., Assefa F., Bo“ rjesson, E., Granhall, U. (2013). Phosphate-solubilising rhizobacteria associated with Coffea arabica L. in natural coffee forests of southwestern Ethiopia. Journal of the Saudi Society of Agricultural Sciences. 12, 7384.

[20] Kole, M. M., \& Altosaar, I. (1988). Distribution of Azotobacter in Eastern Canadian soils and in association with plant rhizospheres. Canadian Journal of Microbiology, 34 (3), 815-817.

[21] Wakley A, Black I. A (1934). An Examination of the degtjareff method for determining soil organic matter and a proposed modification of the chromic acid titration method. Soil Sci. 37 29-38.

[22] Bray RH, Kurtz LT (1945). Determination of total organic and available forms of phosphorus in soils. Soil Sci., 59: 9-45.
[23] Pikovskaya, R. I., (1948). Mobilization of phosphorus in soil in connection with vital activity of some microbial species Microbiology 17: 362-70.

[24] Ravina, M. D., Acea, M. J. and Carballas, T., (1992). Seasonal fluctuations in microbial populations and available nutrients in forest soil. Biological Fertility of Soils, 16: 198-204.

[25] Smith NR, Daws UT. (1944) The bacteriostatic action of rosebengal in media used for plate counts of soil fungi. Soil Sci. 58: 467-471.

[26] Alam, S., Khalil, S., Najma, A. and Rashid M. (2002). In vitro solubilization of inorganic phosphate by phosphate solubilizing microorganisms (PSM) from maize rhizosphere. Int. J. Agric. Biol. 4, 454-458.

[27] Murphy, J., Riley, J. P., (1962). A modified single solution method for determination of phosphate in natural waters. Analytica Chimica Acta 27, 31-36.

[28] Kumari, P. D. Nanayakkara, J. M. and Bandara, J. M. (2010) "Development of a fungal inoculum for efficient phosphate utilization in agriculture," in Proceedings of the 15th International Forestry and Environment Symposium 26-27 Department of Forestry and Environmental Science, University of Sri Jayewardenepura, Nugegoda, Sri Lanka.

[29] Patten, C. L. and Glick, B. R. (1996)"Bacterial biosynthesis of indole- 3-acetic acid," Canadian Journal of Microbiology, vol. 42 , no. 3 , pp. $207-220$.

[30] Cappuccino, J. C., Sherman, N., (1992). In: Microbiology: A Laboratory Manual, third ed. Benjamin/cummings Pub. Co., New York, pp. 125-179.

[31] Lorck, H., (1948). Production of hydrocyanic acid by bacteria. Physiol. Plant. 1, 142-146.

[32] Alstrom, S., and Burns, R. G. (1989). Cyanide production by rhizobacteria as a possible mechanism of plant growth inhibition. Biol. Fertil. Soils. 7: 232-238.

[33] Jensen H L, (1942) Nitrogen fixation in leguminous plants. 1. General characteristics of root-nodule bacteria isolated from species of Medicago and ZX olium in Australia. Proc. Linn. Sot. N. S. W. 66 98-108.

[34] Suman B, Triveni S, Latha PC, Srilatha M and Durga Rani CHV (2018) Salinity tolerant phosphorous solubilising bacteria from saline soils of Telangana. Journal of Pharmacognosy and Phytochemistry. 7 (6): 175-182.

[35] Hayat, R., Khalid, R., Ehsan, M., Ahmed, I., Yokota, A. and Ali, S. (2013). Molecular characterization of soil bacteria for improving crop yield in Pakistan. Pak. J. Bot., 45: 10451055 .

[36] Holt JG, Krieg NR, Sneath PHA, Staley JT, Williams ST. (1994) In: Bergy's Manual of Determinative Bacteriology, ninth ed. Williams and Wilkins Pub., MD, USA.

[37] Balachew, B., Atero, B., Tefera, F., Ayano, A. and Benti, T. (2008). Genetic diversity and Heterosis in Arabica Coffee PP: 50-58. in: Girma Adunya, Bayeta Belachew, Tesfaye Shimbir, Endale Taye and Taye Kufa (eds).

[38] Biradar IB, Raghuramulu Y, Muralidhara HR, Sudhakar SB (2006) Effect of Bio-fertilizers and PGPRS on growth and development of coffee seedlings. J Coffee Research 34: 5763. 
[39] Islam, S., Akanda, M. A., Prova, A., Islam, M. T., Hossain, M. M., (2016). Isolation and identification of plant growth promoting rhizobacteria from cucumber rhizosphere and their effect on plant growth promotion and disease suppression. Front. Microbiol. 6, 1360.

[40] London, J. R. (Ed.), (1991). Booker Tropical Soil Manual: A Handbook for Soil Survey and Agricultural Land Evaluation in the Tropics and Subtropics. Longman.

[41] FAO (1990). Guideline for Soil Description. Rome, Italy, pp: 193.

[42] Babu Vinod S., Triveni, S., Subhash Reddy, R., Sathyanarayana, J. (2017). Isolation and characterization of phosphate Solubilizing microorganisms from Maize Rhizosperic Soils. Bull. Env. Pharmacol. Life Sci., Vol 6 Special issue (1): 194-200.

[43] Dhurve, NG., Ingle, RW., Lad, RS. and Madavi, PN. (2017) Characterization of phosphate solubilizing bacteria isolated from paddy rhizosphere of Vidarbha region. Int. J. of Chemical Studies. 5 (6): 24-30.

[44] Karpagam, T. and Nagalakshmi, P. K. (2014) Isolation and characterization of Phosphate Solubilizing Microbes from Agricultural soil. Int. J. Curr. Microbiol. App. Sci. 3 (3): 601614.

[45] Jeon, J. S., Lee, S-S., Kim, H-Y., Ahn, T-S. \& Song, H-G. (2003) Plant growth promotion in soil by some inoculated microorganisms. J. Microbiol., 41, 271-276.

[46] Sharma, B., Sayyed, Z., Trivedi, H., and Gobi A. (2013). Phosphate solubilizing microbes: sustainable approach for managing phosphorus deficiency in agricultural soils. a SpringerOpen Journal 2: 587.

[47] Nautiyal, C. S., Bhadauria, S., Kumar, P., Lal, H., Mondal, R. \& Verma, D. (2000) Stress induced phosphate solubilization in bacteria isolated from alkaline soils. FEMS Microbiology letters, 182, 291-296.

[48] Spaepen S, Vanderleyden J and Remans R (2007) Indole-3acetic acid in microbial and microorganism-plant signaling. FEMS Microbiol Rev 31: 425-448.

[49] Mohite, B. (2013) Isolation and characterization of indole acetic acid (IAA) producing bacteria from rhizospheric soil and its effect on plant growth. JSS Plant Nutrition, 13 (3), 638-649.

[50] Ghosh, S., Penterman, J. N., Little, R. D., Chavez, R., Glick, B. R. (2003). Three newly isolated plant growth-promoting bacilli facilitate the seeding growth of canola, Brassica campestris plant Physol. Biochem. 41, 277-281.

[51] Gusain, Y. S., Kamal, R., Mehta, CM., Singh, US., and Sharma, AK., (2015) Phosphate solublizing and indole-3acetic acid producing bacteria from the soil of Garwal Himalaya aimed to improve the growth of rice. J. Environ. Biol., 30: 301-307.

[52] Wani PA, Khan MS, Zaidi A, (2007) Co-inoculation of nitrogen-fixing and phosphate-solubilizing bacteria to promote growth, yield and nutrient uptake in chickpea. Acta Agronomica Hungarica, 55 (Suppl 3): 315-323.

[53] Meena, B., Marimuthu, T., Vidhyasekaran, P. and Velazhahan, R. (2001) Biological control of root rot of groundnut with antagonistic Pseudomonas fluorescens strains. J. Pl. Dis.
Protect., 108: 369-381.

[54] Ramette, A., Loy, M. and Defago, G. (2006) Genetic diversity and biocontrol protection of fluorescens pseudomonas producing phloroglucinols and hydrogen cyanide from swiss soils naturally suppressive or conducive to Thieviopsis basicola mediated black rot of tobacco. FEMS Microbial Ecol., 55 (3): 369-381.

[55] Ahmad F, Ahmad I, Khan MS, (2008) Screening of free-living rhizospheric bacteria for their multiple plant growth promoting activities. Microbial Research, 163 (Suppl 2): 17381 .

[56] Muthukumarasamy, R., Kang, UG., Park, KD., Jeon, WT., Park, CY. Cho, Y. S., Kwon, S. W., Song, J., Roh, D. H. and Revathi, G (2007). Enumeration, isolation and identification of diazotrophs from Koreanwetland rice varieties grown with long-term application of $\mathrm{N}$ and compost and their short-term inoculation effect on rice plants. J Appl. Microbiol. 102: 981991.

[57] He, H., Ye, Z., Yang, D., Yan, J., Xiao, L., Zhong, T., Yuan, M., Cai, X., Fang, Z. and Jing, Y. (2013) Characterization of endophytic Rahnella sp. JN6 from Polygonum pubescens and its potential in promoting growth and $\mathrm{Cd}, \mathrm{Pb}, \mathrm{Zn}$ uptake by Brassica napus. Chemosphere. 90, 1960-1965.

[58] Madhaiyan, M., Saravanan, V. S., Bhakiya Silba Sandal Jovi, D., Lee, H., Thenmozhi, R., Hari, K. and Sa, T. M.: (2004) Occurrence of Gluconacetobacter diazotrophicus in tropical and subtropical plants of Western Ghats, India. Microbiol. Res., 159: 233-243.

[59] Gupta, N., Sabat, J., Parida, R. and Karbatta, D. (2007). Solublization of tricalcium phosphatenand rock phosphate by microbes isolated from cromite, iron and manganese mines. Acta Bot. Croat., 66: 197-204.

[60] Rinu, K., Pandey, A., (2010). Temperature-dependent phosphate solubilization by old tolerant species of Aspergillus isolated from Himalayan Soil. Mycoscience 51, 263-271.

[61] Son HJ, Park GT, Cha MS, Heo MS. (2006). Solubilization of insoluble inorganic phosphates by a novel saltand $\mathrm{pH}$-tolerant Pantoea agglomerans R-42 isolated from soybeanrhizosphere. Bioresource Technol. 97 (2): 204 \pm 210.

[62] Chakraborty BN, Chakraborty U, Saha A Sunar K. Dey, P. L. (2010). Evaluation of phosphate solubilizers from soils of North Bengal and their diversity analysis. J Agri Sci 6: 195-200.

[63] Cunningham JE and Kuiack C. (1992). Production of citric and oxalic acids and solubilization of calcium phosphate by Penicillium bilaii. Appl Environ Microbiol. 58 (5): 1451 \pm 1458. PMID: 1622211.

[64] Li X, Luo L, Yang J, Li B, Yuan H. (2015). Mechanisms for solubilization of various insoluble phosphates and activation of immobilized phosphates in different soils by an efficient and salinity-tolerant Aspergillus niger strain An2. Appl Biochem Biotech. 175 (5): 2755-2768.

[65] Nenwani V, Doshi P, Saha T, Rajkumar S. (2010). Isolation and characterization of a fungal isolate for phosphate solubilization and plant growth promoting activity. $\mathrm{J}$ of Yeast and Fungal Res 1: 9-14.

[66] Park, J., Bolan, N., Megharaj, M. and Naidu, R. (2010). Isolation of Phosphate-Solubilizing Bacteria and their Effects Characterization of on Lead Immobilization. Pedologist. 67-75. 
[67] Bertrand H, Nalin R, Bally R, Cleyet-Marel JC. (200) Isolation and identification of the most efficient plant growthpromoting bacteria associated with canola (Brassica napus). Biol Fertil Soils; 33: 152-156.

[68] Khalid A, Arshad M and Zahir ZA. (2004). Screening plant growth-promoting rhizobacteria improving growth and yield of wheat. J Appl Microbiol; IJPBA, Jan 96: 473480.
[69] Yilmaz EI. (2003) Metal tolerance and biosorption capacity of Bacillus circulans strain EBI. Res Microbiol; 154: 409-415.

[70] Herma, M. A. B., Nault, B. A., Smart, C. D., (2008). Effects of plant growth-promoting rhizobacteria on bell pepper production and green peach aphid infestations in New York. Crop Protec, 27, 996-1002. 